\title{
$\begin{array}{r}\text { WAGENINGEN } \\ \text { UNIVERSITY \& RESEARCH } \\ \hline\end{array}$
}

\author{
Redox-flow battery design for a methane-producing bioelectrochemical \\ system \\ Geppert, F., Liu, D., Weidner, E., \& ter Heijne, A.
}

This is a "Post-Print" accepted manuscript, which has been Published in "International Journal of Hydrogen Energy"

This version is distributed under a non-commercial no derivatives Creative Commons (c) $)(1) \Theta($ (CC-BY-NC-ND) user license, which permits use, distribution, and reproduction in any medium, provided the original work is properly cited and not used for commercial purposes. Further, the restriction applies that if you remix, transform, or build upon the material, you may not distribute the modified material.

Please cite this publication as follows:

Geppert, F., Liu, D., Weidner, E., \& ter Heijne, A. (2019). Redox-flow battery design for a methane-producing bioelectrochemical system. International Journal of Hydrogen Energy, 44(39), 21464-21469.

https://doi.org/10.1016/j.ijhydene.2019.06.189

You can download the published version at:

https://doi.org/10.1016/j.ijhydene.2019.06.189 


\section{Redox-Flow Battery Design for a Methane-Producing}

\section{BIOELECTROCHEMICAL SYSTEM}

3 Florian Geppert ${ }^{\mathrm{a}, \mathrm{b}}$, Dandan Liuc ${ }^{\mathrm{c}}$, Eckhard Weidner ${ }^{\mathrm{a}, \mathrm{b}}$, Annemiek ter Heijne $\mathrm{c}^{\mathrm{c}^{*}}$

${ }^{a}$ Fraunhofer Institute for Environmental, Safety, and Energy Technology UMSICHT, Osterfelder Str. 3, 46047 Oberhausen, Germany

${ }^{\mathrm{b}}$ Ruhr-University Bochum, Department of Mechanical Engineering, Universitätsstr. 150, 44801 Bochum, Germany

${ }^{c}$ Wageningen University, Sub-Department of Environmental Technology, Bornse Weilanden 9, 6708 WG Wageningen, The Netherlands

*Correspondence:annemiek.terheijne@wur.nl (A. ter Heijne)

Keywords: Bioelectrochemical power-to-gas, Reactor design, Methane, Biocathode, Methanogenic archaea

\section{ABstract}

Methane production at biocathodes is an innovative approach of storing renewable electrical energy in chemical energy via the biological conversion of carbon dioxide. Methane-producing microorganisms use electricity to catalyze the conversion of carbon dioxide into methane; a form of carbon-neutral natural gas. However, the rates of methane production remain too low for practical application. To improve performance, high area-to-volume ratio with good mass transfer is required.In this study, we used the design of redox flow-batteries with a high areato-volume ratio of $2.0 \mathrm{~cm}^{-1}$ and an external capillary manifold for flow distribution . Current densities up to $35 \mathrm{~A} / \mathrm{m}^{2}$ were applied, resulting in volumetric methane production rates of up to $12.5 \mathrm{~L} \mathrm{CH}_{4} / \mathrm{L} / \mathrm{d}, 3$ times higher than rates reported so far. The highest energy efficiency of $30 \%$ was obtained at $25 \mathrm{~A} / \mathrm{m}^{2}$. Even with a low relative abundance of methanogens in the microbial community (20\%), dense biofilm growth was observed on the outer surface of the biocathode. Flow-battery cell design shows promising performance for application of methane-producing biocathodes. 


\section{INTRODUCTION}

The increasing global energy demand not only results in a faster depletion of fossil fuels but also in an increased emission of carbon dioxide [1]. Hence, it is necessary to shift from nuclear and fossil energy sources towards renewable energy sources. However, the generation of renewable electricity is depending on intermittent energy sources like wind and sun. Due to the natural fluctuations of these energy sources, it is required to develop energy storage technologies [2].

Power-to-gas is a storage technology in which electrical energy is converted into chemical energy in the form of methane [3]. Recently, methane-producing bioelectrochemical systems (BESs) have emerged as a novel biological power-to-gas technology [4]. In such systems, water is typically oxidized at the anode, and hence functions as electron donor [5], while methane is generated via microorganisms located on or in the vicinity of the cathode from direct (via electrons) and/or indirect (via hydrogen) conversion of carbon dioxide[6].

The reported methane production rates are still low, ranging between 0.13-30 $\mathrm{L} \mathrm{CH}_{4} / \mathrm{m}^{2} /$ day [4]. Recently, it was demonstrated that by controlling the current (galvanostatic operation) at $35 \mathrm{~A} / \mathrm{m}^{2}$, methane production rates were increased up to $60 \mathrm{~L} \mathrm{CH}_{4} / \mathrm{m}^{2} /$ day [7]. To increase methane production rates further, it is crucial to design reactors with low distance between anode and cathode, and with good flow distribution to minimize mass transfer limitations.

The aim of this study was to improve the performance of methane-producing bioelectrochemical system by adapting a reactor design typical for redox-flow batteries [8], with electrodes positioned close to each other $(0.5 \mathrm{~cm}$ compartment thickness). Moreover, external manifolds for liquid recirculation were used to ensure good mass transfer, according to [9]. Experiments were conducted in galvanostatic mode at current densities up to $35 \mathrm{~A} / \mathrm{m}^{2}$. For each tested current density, the performances in terms of methane production rate, current-to-methane efficiency as well as the energy efficiency were assessed. Finally, the biofilm development and the microbial community have been analyzed via scanning electron microscopy (SEM) and DNA sequencing. 


\section{Materials and Methodology}

\subsection{Experimental Set-Up}

A redox-flow battery design reactor was used, containing an anode and cathode chamber. Each chamber had a volume of $85 \mathrm{~cm}^{3}(13.0 \mathrm{~cm}$ length $\times 13.0 \mathrm{~cm}$ width $\times 0.5 \mathrm{~cm}$ thickness $)$. The chambers were separated via a cation exchange membrane with an effective surface area of $169 \mathrm{~cm}^{2}$ (Nafion 117, Dupont, USA). The electrolyte was supplied to and collected from each compartment via external manifolds with eleven capillaries, each with an inner diameter of $3.0 \mathrm{~mm}$. These capillaries were wielded into holes located on two opposite sides of both electrolyte frames [9] (Figure1). An iridium-oxide coated titanium mesh (Typ G, mesh: $4.0 \mathrm{x}$ $2.0 \times 0.5 \times 0.5 \mathrm{~mm}, 12 \mathrm{~g} \mathrm{Ir} / \mathrm{m}^{2}$, Metakem $\mathrm{GmbH}$, Germany) was used as anode. The anode was placed directly on the (untreated) membrane. The remaining space in the anode compartment was filled with three layers of spacer cloth material (Vileda 1174 2-phase haze filter, Vileda, Gemany). The cathode consisted of two layers of $4.6 \mathrm{~mm}$ thick graphite felt (specific surface area: $0.4 \mathrm{~m}^{2} / \mathrm{g}$; GFD 4.6, SGL Carbon Group, USA), compressed to fill the cathode chamber. The graphite felts were heat-treated for $4 \mathrm{~h}$ at $390{ }^{\circ} \mathrm{C}$ in an air circulation oven before use, in order to increase hydrophilicity of the material. A bipolar plate (Sigracet TF6, SGL Carbon Group, USA) was used in connection to a nickel coated copper plate, functioning as current collector, to prevent release of nickel or copper ions into the catholyte. Two reference electrodes (3M KCl Ag/AgCl, QIS, Oosterhout, the Netherlands, $+0.205 \mathrm{~V}$ vs standard hydrogen electrode) were installed. The anodic reference electrode was installed in proximity of the anode chamber, while the cathodic reference electrode was directly inserted into the cathode compartment. The catholyte (total volume of $3.0 \mathrm{~L}$ ) was recirculated via a liquid-gas separation bottle and a catholyte recirculation bottle. The anolyte was also recirculated via a 3.0 $\mathrm{L}$ anolyte recirculation bottle. The recirculation speed of both anolyte and catholyte was $85 \mathrm{~mL} / \mathrm{min}$. 


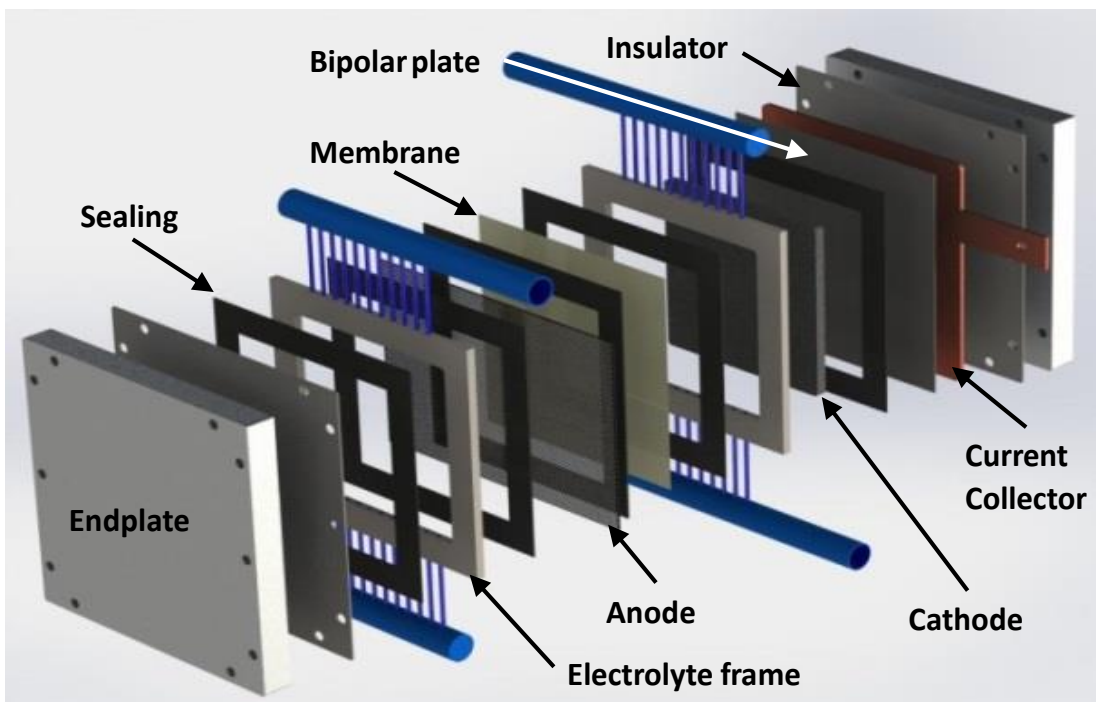

Figure1.Exploded view of the redox flow battery design, used as reactor. An external capillary manifold was attached to the electrode chamber frame to improve electrolyte distribution. Remaining space in the anode compartment was filled with three layers of spacer material (not shown in this figure).

\subsection{Electrolytes and Inoculum}

The base medium for both catholyte and anolyte was a $40 \mathrm{mM}$ phosphate buffer $(2.72 \mathrm{~g} / \mathrm{L}$ $\mathrm{KH}_{2} \mathrm{PO}_{4}$ and $3.55 \mathrm{~g} / \mathrm{L} \mathrm{Na} \mathrm{HPO}_{4} \cdot 2 \mathrm{H}_{2} \mathrm{O}$ ). The catholyte additionally contained macronutrients $\left(0.28 \mathrm{~g} / \mathrm{L} \mathrm{NH} \mathrm{Cl}_{4} 0.0076 \mathrm{~g} / \mathrm{L} \mathrm{CaCl} \cdot 2 \mathrm{H}_{2} \mathrm{O}, 0.01 \mathrm{~g} / \mathrm{L} \mathrm{MgSO} \cdot 7 \mathrm{H}_{2} \mathrm{O}\right.$, and $\left.0.09 \mathrm{~g} / \mathrm{L} \mathrm{MgCl} \cdot 6 \mathrm{H}_{2} \mathrm{O}\right)$, $1 \mathrm{~mL} / \mathrm{L}$ of a micronutrient solution as described in [10] and $1 \mathrm{~mL} / \mathrm{L}$ of a vitamin solution as described in [11]. As carbon source, sodium bicarbonate was added to the catholyte in a concentration of $5.0 \mathrm{~g} / \mathrm{L}$.

The catholyte was inoculated with $250 \mathrm{~mL}$ of a non-enriched consortium of microorganisms $(20.5 \pm 1.2 \mathrm{~g} / \mathrm{L}$ of volatile suspended solids (VSS)) from the Loick Bioenergie GmbH biogas plant after sieving (mesh size: $1 \mathrm{~mm}$ ).

\subsection{Operational Conditions}

The biocathode was galvanostatically controlled (fixed current) by a potentiostat (PP201, ZAHNER-elektrik GmbH \& Co. KG, Germany) and cathode potentials were recorded every minute. Catholyte temperature was controlled at $30.0^{\circ} \mathrm{C}$ and catholyte $\mathrm{pH}$ was controlled at 7.0 via a pH controller (modified device; Liquisys, Endress+Hauser, Germany).

Before inoculation, the reactor was characterized abiotically at a current density of $5 \mathrm{~A} / \mathrm{m}^{2}$, normalized to cathode projected surface area. After inoculation, the same current density of $5 \mathrm{~A} / \mathrm{m}^{2}$ was used for the biocathode start-up period, which lasted until performance was 
stable (27 days). Then, the current density was increased to $10,15,25$, and $35 \mathrm{~A} / \mathrm{m}^{2}$. The cathode was operated in fed-batch mode. The duration depended on the applied current density and ranged from 7 days to less than a day at $35 \mathrm{~A} / \mathrm{m}^{2}$, due to a faster depletion of carbon dioxide. After each current density, $2 \mathrm{~L}$ of the catholyte was exchanged with fresh medium under nitrogen flushing to prevent depletion of nutrients and bicarbonate.

\subsection{Chemical Analysis Methods and Calculations}

Methane production rate, current-to-methane efficiency and energy efficiency were analyzed. Gas samples were collected in a gas sampling bag (GSB-P/10, Dr.-Ing.Ritter Apparatebau $\mathrm{GmbH} \&$ Co.KG, Germany). The volume of gas production inside the gas sampling bag was quantified by syringe and analyzed for the concentrations of methane and carbon dioxide online via a biogas analyzer (BenchOne, BlueSens, Germany); content of hydrogen, oxygen and nitrogen were analyzed via gas chromatography (for details on these measurements see SI).

Current, methane, and hydrogen production rates were normalized to the projected cathode surface area $\left(169 \mathrm{~cm}^{2}\right)$ and/or to the volume of the cathode chamber $\left(84.5 \mathrm{~cm}^{3}\right)$. Current-tomethane efficiency and energy efficiency were calculated according to [4].

\subsection{Polarization Curves}

Polarization curves were recorded at the end of each batch by measuring the current at every $10 \mathrm{~s}$ when decreasing the cathode potential from -0.2 to $-0.9 \mathrm{~V}$ vs. SHE with a step width of $0.05 \mathrm{~V}$ and a step duration of $300 \mathrm{~s}$. The last 10 data points (100 s) at each cathode potential were averaged.

\subsection{Scanning Electron Microscopy}

Electrode samples were cut from the biocathode immediately after opening the reactor and directly fixed for $2 \mathrm{~h}$ in $2.5 \%$ glutaraldehyde in phosphate-buffered-saline (PBS) solution consisting of $8.00 \mathrm{~g} / \mathrm{L} \mathrm{NaCl}, 0.20 \mathrm{~g} / \mathrm{L} \mathrm{KCl}, 1.78 \mathrm{~g} / \mathrm{L} \mathrm{Na}_{2} \mathrm{HPO}_{4} \cdot 2 \mathrm{H}_{2} \mathrm{O}$ and $0.27 \mathrm{~g} / \mathrm{L} \mathrm{KH}_{2} \mathrm{PO}_{4}(\mathrm{pH} 7.4)$. Each sample was washed with PBS buffer for three times with each washing step lasting for $15 \mathrm{~min}$, before dehydrating the samples in an ascending ethanol dilution series $(10,25,50,75$, and $90 \%(\mathrm{v} / \mathrm{v}), 20 \mathrm{~min}$ each, and finally in 100\% (v/v) ethanol for $30 \mathrm{~min}$. The samples were treated for 20 min with bis(trimethylsilyl)amine (hexamethyldisilazane, HMDS) and dried in a desiccator overnight. After sputter coating the samples with a $5.0 \mathrm{~nm}$ thin gold layer, they 
were placed at high vacuum with a Tescan Vega3 scanning electron microscope at $20 \mathrm{kV}$ accelerating voltage.

\subsection{Microbial Community Analysis}

Biofilm samples ( $0.1 \mathrm{~g}$ wet weight) of the graphite felts facing the membrane and the current collector were collected for microbial community analysis. DNA samples from the biofilm samples were extracted by using the PowerSoil DNA Isolation Kit (MO BIO Laboratories, Carlsbad, CA, USA). Bacterial and archaeal 16S rDNA gene fragments were amplified and analyzed according to [12].

\section{RESULTS AND DISCUSSION}

\subsection{Effect of Current Density on Methane production rates}

With increasing current densities from $5 \mathrm{~A} / \mathrm{m}^{2}$ to $35 \mathrm{~A} / \mathrm{m}^{2}$, the volumetric methane production rates increased almost linearly from $1.0 \mathrm{~L} \mathrm{CH}_{4} / \mathrm{L} / \mathrm{d}$ to $13.0 \mathrm{~L} \mathrm{CH}_{4} / \mathrm{L} / \mathrm{d}$ (Figure 2A). Current-tomethane efficiencies increased from about $35 \%$ at $5 \mathrm{~A} / \mathrm{m}^{2}$ to about $65 \%$ at $15 \mathrm{~A} / \mathrm{m}^{2}$, and remained at $60-65 \%$ at higher current densities (Figure 2B). Hydrogen production increased with increasing current densities, which is likely the result of limited methanogenic activity in relation to the supplied current. The energy efficiency ranged between 19 and 30\%; the highest energy efficiency of $30 \%$ was obtained at $25 \mathrm{~A} / \mathrm{m}^{2}$.

A
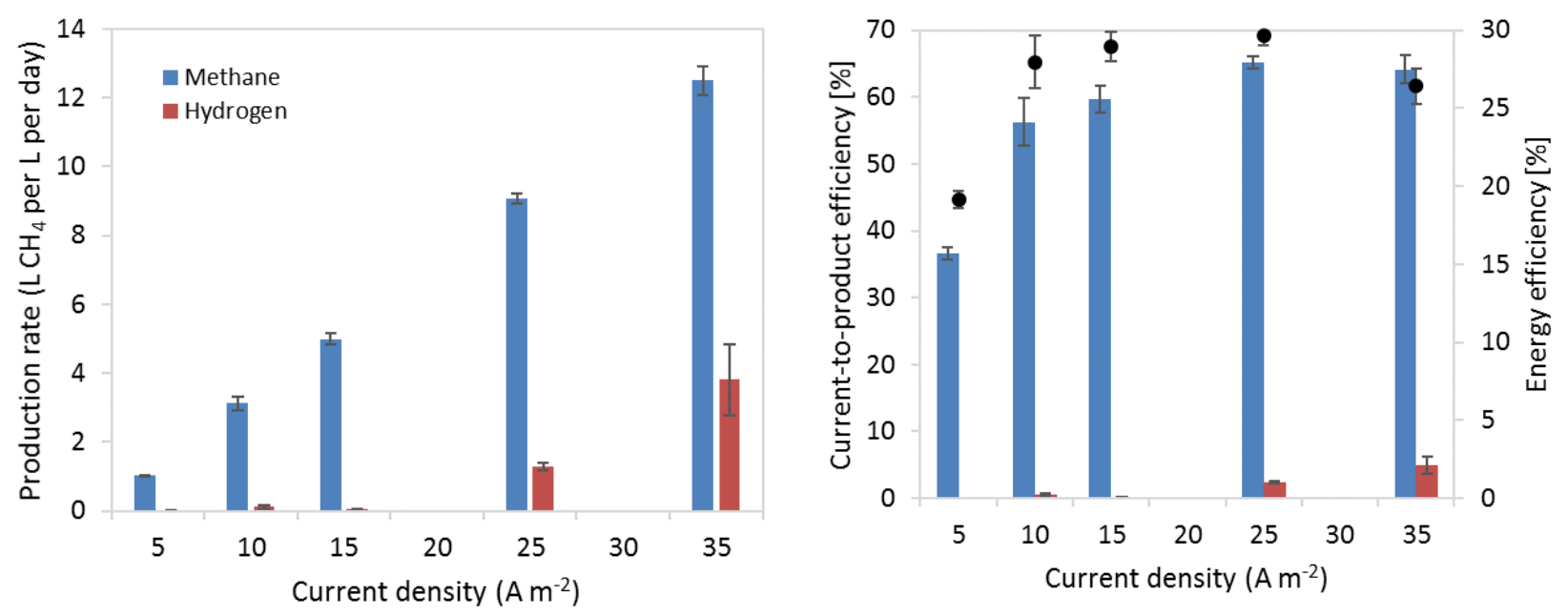
Figure 2. A: Production rates of methane (blue) and hydrogen (red) at the different applied current densities. B: Current-to-product efficiencies of methane (blue) and hydrogen (red) and energy efficiencies (black dots, second y-axis) at different applied current densities.

The cathode potential during galvanostatic operation was approximately $-0.75 \mathrm{~V}$ vs. SHE at the lower applied current densities of 5 to $15 \mathrm{~A} / \mathrm{m}^{2}$, decreased to $-0.85 \mathrm{~V}$ vs SHE at $25 \mathrm{~A} / \mathrm{m}^{2}$ and finally to $-1.1 \mathrm{~V}$ vs SHE at $35 \mathrm{~A} / \mathrm{m}^{2}$ (Figure $3 \mathrm{~A}$ ). Polarization curves showed that the biocathode performance initially increased between 5 and $15 \mathrm{~A} / \mathrm{m}^{2}$, but then decreased with time at current densities higher than $15 \mathrm{~A} / \mathrm{m}^{2}$ (Figure 3B). A possible cause for this decline in performance is that methanogenic activity was not sufficiently high to convert all current into methane (as also reflected in the higher hydrogen production rate). Therefore, hydrogen evolution occurred and higher hydrogen partial pressure in turn elevated cathodic overpotential for hydrogen evolution reaction [13].

A

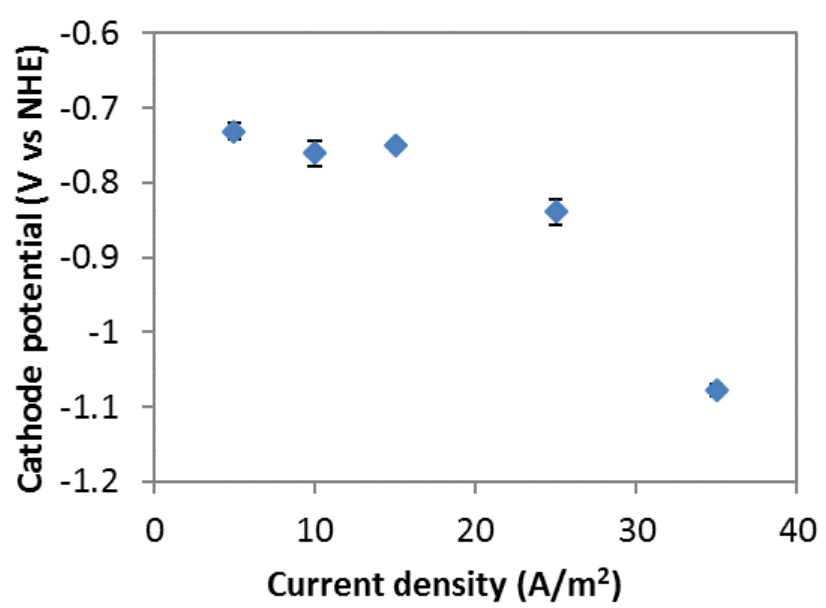

B



Figure 3. Cathode potentials (A) and Polarization curves (B) for each applied current density. Polarization curves were recorded at each cathode potential. From the polarization curves, initially an improvement was seen during which the applied current density was increased from 5 to $15 \mathrm{~A} / \mathrm{m}^{2}$, while after increasing the applied current density to 25 and even $35 \mathrm{~A} / \mathrm{m}^{2}$, cathode performance deteriorated. This is also reflected in the sharp decrease in cathode potential at 25 and $35 \mathrm{~A} / \mathrm{m}^{2}$.

\subsection{Biofilm and Microbial Community Analysis}

SEM pictures were taken from the felt at different locations to analyze the distribution of microorganisms (see Supporting Information). Almost no biofilm was observed on the inner 
part of the felts (Figure S1A), which is in line with observations in other studies [14]. A dense biofilm was observed across the graphite felt biocathode, at the electrode surface facing the membrane and the bipolar plate/current collector assembly (Figure S1B and S1C). Mostly rodshaped microorganisms with sizes around $1 \mu \mathrm{m}$ were observed on the graphite felt facing the membrane (Figure S1D).

The results of microbial community analysis showed a $20 \%$ abundance of Archaea, with the other $80 \%$ being Bacteria (Figure 4). Different communities were found on the membrane side and the current collector side of the electrode. At the current collector side, high relative abundances of both Methanobacteriaceae and Methanomicrobia were found. Both are hydrogenotrophic methanogens and have been observed at methane-producing biocathodes in many previous studies $[4,6,7]$. The presence of members of Firmicutes, such as Clostridium sp., supported the hypothesis that hydrogen was an active intermediate [15]. At the membrane side, besides the dominant Methanobacteriaceae, Proteobacteria were detected as the most dominant bacteria ( $81 \%$ of bacterial community). Especially, Epsilonproteobacteria, which generate energy by oxidizing hydrogen using oxygen as electron acceptor [16], was the most abundant bacterial genus in this location (49\% of microbial community) and likely had a role as oxygen scavenger near the membrane.

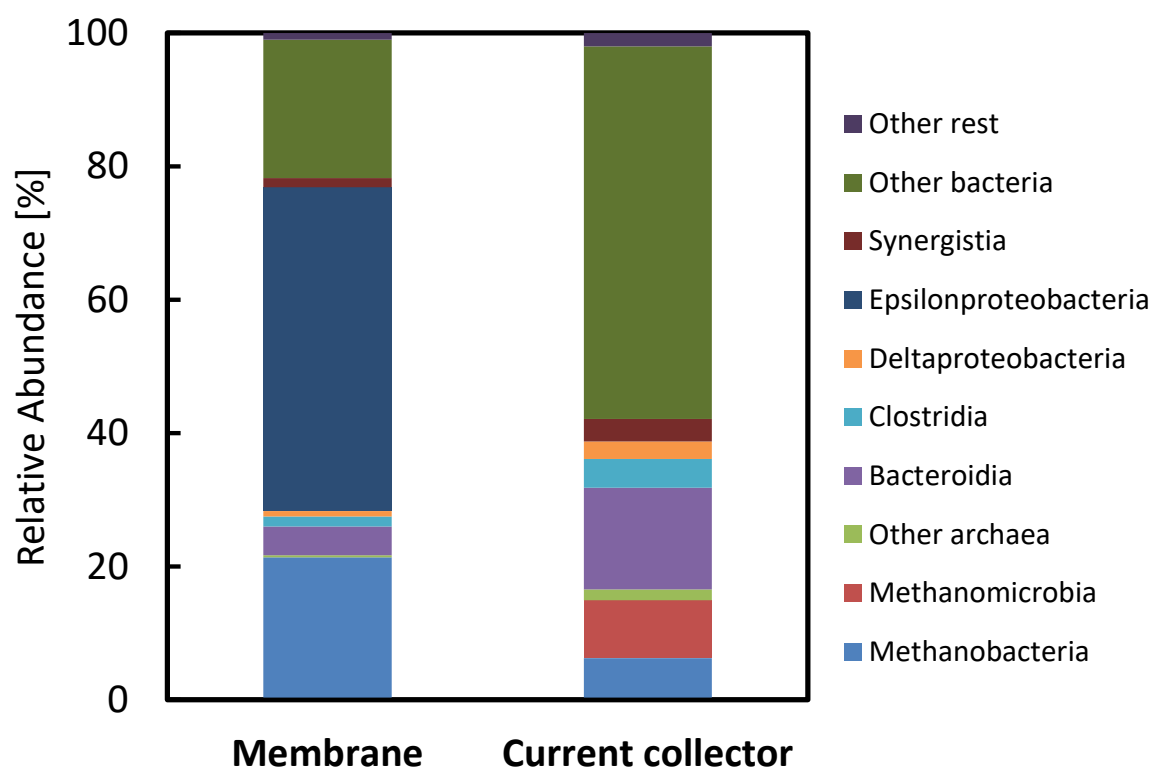

Figure 4. Taxonomic distribution of the biofilm on the graphite felt facing the membrane and the current collector. The abundance of methanogens was low, around $20 \%$, while the rest of the microbial populations consisted of bacteria. Differences between membrane and current collector side are likely related to the availability of oxygen. 


\subsection{Outlook}

193 An overview of the performances of methane producing biocathodes is shown in Table 1.

194 Compared to other studies, high methane production rates were achieved with the redox195 flow battery design, especially when these rates are normalized to cathode volume. This is 196 related to the high area to volume ratio $\left(2.0 \mathrm{~cm}^{2} / \mathrm{cm}^{3}\right)$ compared to other studies (all lower 197 than $0.9 \mathrm{~cm}^{2} / \mathrm{cm}^{3}$ ). Moreover, other studies, which also achieved high methane production 198 rates [7] often have small projected surface areas compared to the reactor design used herein, 199 whereas the performance in studies using reactors with larger projected surface areas [5] had low methane production rates. The fact that larger reactors achieve lower rates may be related to the fact that the medium distribution in large reactors has not always been optimized, leading to a non-even distribution of reactor solution and mass transfer limitations. Hence, the manifold design with several in- and outlets in this study is believed to be directly related to the results obtained in this study. The mixing of the catholyte via the external manifold has been demonstrated for redox-flow battery application [17] shown to result in homogeneously distributed reactor solutions. 
Table1. Key parameters of this study in comparison to data of other mixed culture methane-producing

209 bioelectrochemical systems using water oxidation at the anode. Values have been normalized to 210 cathode projected surface area and cathode chamber volume, at standard temperature and pressure 211 (STP, $298.15 \mathrm{~K}$ and 1 bar).

\begin{tabular}{|c|c|c|c|c|c|c|c|c|c|}
\hline \multirow[b]{2}{*}{$\begin{array}{c}\text { Cathode } \\
\text { potential } \\
\text { [V vs. SHE] }\end{array}$} & \multirow[b]{2}{*}{$\begin{array}{c}\text { Electrode } \\
\text { material }\end{array}$} & \multicolumn{2}{|c|}{ Current density } & \multicolumn{2}{|c|}{$\begin{array}{c}\text { Methane } \\
\text { production } \\
\text { rate }\end{array}$} & \multirow[b]{2}{*}{$\begin{array}{c}\text { Current- } \\
\text { to- } \\
\text { methane } \\
\text { efficienc } \\
y[\%]\end{array}$} & \multirow{2}{*}{$\begin{array}{l}\text { Projecte } \\
\quad d \\
\text { cathode } \\
\text { surface } \\
\text { area } \\
{\left[\mathrm{cm}^{2}\right]}\end{array}$} & \multirow{2}{*}{$\begin{array}{l}\text { Catho } \\
\text { de } \\
\text { surfac } \\
\text { e } \\
\text { area- } \\
\text { to- } \\
\text { volum } \\
\text { e ratio } \\
\text { [SA/V, } \\
\left.\mathrm{cm}^{-1}\right]\end{array}$} & \multirow[b]{2}{*}{ Ref. } \\
\hline & & {$\left[\mathrm{A} / \mathrm{m}^{2}\right]$} & {$\left[\mathrm{kA} / \mathrm{m}^{3}\right]$} & $\begin{array}{l}{\left[\mathrm{L}_{\mathrm{CH} 4} /\right.} \\
\left.\mathrm{m}^{2} / \mathrm{d}\right]\end{array}$ & $\begin{array}{c}{\left[\mathrm{L}_{\mathrm{CH} 4}\right.} \\
/ \mathrm{L} / \mathrm{d} \\
]\end{array}$ & & & & \\
\hline-0.32 & $\begin{array}{c}\text { Activated } \\
\text { carbon } \\
\text { granules }\end{array}$ & 10.0 & 0.7 & 14.8 & 1.0 & 54 & 22 & 0.7 & [7] \\
\hline-0.38 & $\begin{array}{l}\text { Activated } \\
\text { carbon } \\
\text { granules }\end{array}$ & 35.0 & 2.5 & 63.9 & 4.2 & 67 & 22 & 0.7 & [7] \\
\hline-0.50 & Carbon cloth & 0.2 & $2 * 10^{-4}$ & 1.6 & 0.1 & 93 & 80 & 0.2 & [18] \\
\hline-0.55 & Graphite felt & 0.2 & 0.1 & 0.1 & 0.01 & 23 & 250 & 0.9 & [5] \\
\hline-0.70 & Graphite felt & 2.9 & 1.0 & 5.1 & 0.5 & 73 & 250 & 0.9 & [5] \\
\hline-0.70 & $\begin{array}{l}\text { Graphite } \\
\text { granules }\end{array}$ & 10.0 & 0.7 & 15.0 & 1.0 & 52 & 22 & 0.7 & [7] \\
\hline-0.75 & Carbon felt & 3.4 & 0.1 & 7.4 & 0.1 & 89 & 98 & 0.2 & [19] \\
\hline-0.76 & Graphite felt & 10.0 & 2.0 & 15.7 & 3.1 & 56 & 169 & 2.0 & $\begin{array}{l}\text { This } \\
\text { study }\end{array}$ \\
\hline-0.85 & $\begin{array}{l}\text { Graphite } \\
\text { granules }\end{array}$ & 35.0 & 2.3 & 62.0 & 4.1 & 67 & 22 & 0.7 & [7] \\
\hline-1.08 & Graphite felt & 35.0 & 7.0 & 62.5 & 12.5 & 64 & 169 & 2.0 & $\begin{array}{l}\text { This } \\
\text { study }\end{array}$ \\
\hline
\end{tabular}

213 Anode overpotentials were close to $0.3 \mathrm{~V}$, independent of current density, a value typical for 214 noble metal catalysts [20]. The main irreversible voltage losses occurred at the biocathode.

215 At biological standard conditions ( $298.15 \mathrm{~K}$ and $1 \mathrm{bar}, \mathrm{pH}=7)$, the cathode potential for $\mathrm{CO}_{2}$

216 reduction to methane is about $-0.24 \mathrm{~V}$ [4]. Based on our results (Fig. 3), the cathode

217 overpotential was $0.52 \mathrm{~V}$ at $10 \mathrm{~A} / \mathrm{m}^{2}$, and increased to $0.84 \mathrm{~V}$ at $35 \mathrm{~A} / \mathrm{m}^{2}$. These high

218 overpotentials at the cathode could be the result of limited cathodic microbial coverage and 219 activity [21]. Modifying the cathode surface in order to improve microbial adhesion could be one solution to overcome this limitation [22]. Another strategy is the use of other cathode 
materials, for example granular activated carbon (GAC), as it was recently reported that methane-production biocathodes using GAC at $10 \mathrm{~A} / \mathrm{m}^{2}$ had cathode overpotentials of only $0.06 \vee[7]$.

The redox flow battery design offers opportunities for improving the performance of methane producing BESs, especially when energy losses (overpotentials) at the cathode can be further reduced, for example via modified electrodes or use of different electrode materials.

\section{ACKNOWLEDGEMENTS}

This work is supported by the Cluster of Excellence RESOLV (EXC 1069) funded by the Deutsche Forschungsgemeinschaft.

\section{REFERENCES}

[1] Rogelj, J., den Elzen, M., Höhne, N., Fransen, T., Fekete, H., Winkler, H., Schaeffer, R., Sha, F., Riahi, K., and Meinshausen, M. (2016) Paris Agreement climate proposals need a boost to keep warming well below $2{ }^{\circ} \mathrm{C}$, Nature, 534, 631 .

[2] Hu, J., Harmsen, R., Crijns-Graus, W., Worrell, E., and van den Broek, M. (2018) Identifying barriers to large-scale integration of variable renewable electricity into the electricity market: $\mathrm{A}$ literature review of market design, Renewable and Sustainable Energy Reviews, 81, 2181-2195. [3] Bailera, M., Lisbona, P., Romeo, L. M., and Espatolero, S. (2017) Power to Gas projects review: Lab, pilot and demo plants for storing renewable energy and $\mathrm{CO} 2$, Renewable and Sustainable Energy Reviews, 69, 292-312.
[4] Geppert, F., Liu, D., van Eerten-Jansen, M., Weidner, E., Buisman, C., and ter Heijne, A. (2016) Bioelectrochemical Power-to-Gas: State of the Art and Future Perspectives, Trends in Biotechnology, 34, 879-894.

[5] Van Eerten-Jansen, M. C. A. A., Heijne, A. T., Buisman, C. J. N., and Hamelers, H. V. M. (2012) Microbial electrolysis cells for production of methane from CO2: long-term performance and perspectives, International Journal of Energy Research, 36, 809-819.

[6] van Eerten-Jansen, M. C. A. A., Jansen, N. C., Plugge, C. M., de Wilde, V., Buisman, C. J. N., and ter Heijne, A. (2015) Analysis of the mechanisms of bioelectrochemical methane production by mixed cultures, Journal of Chemical Technology \& Biotechnology, 90, 963-970. 
252 [7] Liu, D., Roca-Puigros, M., Geppert, F., Caizán-Juanarena, L., Na Ayudthaya, S. P., Buisman, C., and

253 ter Heijne, A. (2018) Granular Carbon-Based Electrodes as Cathodes in Methane-Producing

254 Bioelectrochemical Systems, Frontiers in Bioengineering and Biotechnology, 6: 78.

255 [8] Arenas, L. F., Walsh, F. C., and de León, C. P. (2015) 3D-Printing of Redox Flow Batteries for Energy

256 Storage: A Rapid Prototype Laboratory Cell, ECS Journal of Solid State Science and Technology, 4, $257 \quad 3080-3085$.

258 [9] Seipp, T., Dötsch, C., Berthold, S. (2011) Redox-Flow-Batterie mit außenliegender

259 Versorgungsleitung und/oder Entsorgungsleitung, DE102011122010A1.

260 [10] ter Heijne, A., Hamelers, H. V. M., Saakes, M., and Buisman, C. J. N. (2008) Performance of non-

261 porous graphite and titanium-based anodes in microbial fuel cells, Electrochimica Acta, 53, 5697-

2625703.

263 [11] ter Heijne, A., Hamelers, H. V. M., and Buisman, C. J. N. (2007) Microbial Fuel Cell Operation with 264 Continuous Biological Ferrous Iron Oxidation of the Catholyte, Environmental Science \& Technology, $26541,4130-4134$.

266 [12] ter Heijne, A., de Rink, R., Liu, D., Klok, J. B. M., and Buisman, C. J. N. (2018) Bacteria as an 267 Electron Shuttle for Sulfide Oxidation, Environmental Science \& Technology Letters, 5, 495-499.

268 [13] Xiong, X. L., Zhou, Q. J., Li, J. X., Volinsky, A. A., and Su, Y. J. (2017) Cathodic over-potential and 269 hydrogen partial pressure coupling in hydrogen evolution reaction of marine steel under hydrostatic 270 pressure, Electrochimica Acta, 247, 1019-1029.

271 [14] Sleutels, T. H. J. A., Hamelers, H. V. M., Rozendal, R. A., and Buisman, C. J. N. (2009) lon transport 272 resistance in Microbial Electrolysis Cells with anion and cation exchange membranes, International 273 Journal of Hydrogen Energy, 34, 3612-3620.

274 [15] Jourdin, L., Freguia, S., Donose, B. C., and Keller, J. (2015) Autotrophic hydrogen-producing 275 biofilm growth sustained by a cathode as the sole electron and energy source, Bioelectrochemistry, $276102,56-63$.

277 [16] Waite, D. W., Vanwonterghem, I., Rinke, C., Parks, D. H., Zhang, Y., Takai, K., Sievert, S. M., 278 Simon, J., Campbell, B. J., Hanson, T. E., Woyke, T., Klotz, M. G., and Hugenholtz, P. (2018) Erratum: 279 Addendum: Comparative Genomic Analysis of the Class Epsilonproteobacteria and Proposed 280 Reclassification to Epsilonbacteraeota (phyl. nov.), Frontiers in microbiology, 9, 772-772.

281 [17] Seipp, T. (2016) Untersuchung der Stromdichteverteilung in Redox-Flow-Batterien, Verlag Karl 282 Maria Laufen.

283 [18] Fu, Q., Kuramochi, Y., Fukushima, N., Maeda, H., Sato, K., and Kobayashi, H. (2015)

284 Bioelectrochemical Analyses of the Development of a Thermophilic Biocathode Catalyzing 285 Electromethanogenesis, Environmental Science \& Technology, 49, 1225-1232. 
286 [19] Jiang, Y., Su, M., Zhang, Y., Zhan, G., Tao, Y., and Li, D. (2013) Bioelectrochemical systems for 287 simultaneously production of methane and acetate from carbon dioxide at relatively high rate, 288 International Journal of Hydrogen Energy, 38, 3497-3502.

289 [20] Frydendal, R., Paoli, E. A., Knudsen, B. P., Wickman, B., Malacrida, P., Stephens, I. E. L., and 290 Chorkendorff, I. (2014) Benchmarking the Stability of Oxygen Evolution Reaction Catalysts: The 291 Importance of Monitoring Mass Losses, ChemElectroChem, 1, 2075-2081.

292 [21] Van Eerten-Jansen, M. C. A. A., Veldhoen, A. B., Plugge, C. M., Stams, A. J. M., Buisman, C. J. N., 293 and Ter Heijne, A. (2013) Microbial Community Analysis of a Methane-Producing Biocathode in a 294 Bioelectrochemical System, Archaea, 2013, 12.

295 [22] Zhang, T., Nie, H., Bain, T. S., Lu, H., Cui, M., Snoeyenbos-West, O. L., Franks, A. E., Nevin, K. P., 296 Russell, T. P., and Lovley, D. R. (2013) Improved cathode materials for microbial electrosynthesis, 297 Energy \& Environmental Science, 6, 217-224. 


\section{SUPPORTING INFORMATION}

3 Redox-Flow Battery Design for a Methane-Producing

\section{BIOELECTROCHEMICAL SYSTEM}

$5 \quad$ Florian Geppert ${ }^{\mathrm{a}, \mathrm{b}}$, Dandan Liuc ${ }^{\mathrm{c}}$, Eckhard Weidner ${ }^{\mathrm{a}, \mathrm{b}}$, Annemiek ter Heijne ${ }^{\mathrm{c}^{*}}$

6 a Fraunhofer Institute for Environmental, Safety, and Energy Technology UMSICHT,

7 Osterfelder Str. 3, 46047 Oberhausen, Germany

$8{ }^{\mathrm{b}}$ Ruhr-University Bochum, Department of Mechanical Engineering, Universitätsstr. 150,

944801 Bochum, Germany

10 'Wageningen University, Sub-Department of Environmental Technology, Bornse Weilanden 9, 116708 WG Wageningen, The Netherlands

$12{ }^{*}$ Correspondence:annemiek.terheijne@wur.nl (A. ter Heijne)

13 Keywords: Bioelectrochemical power-to-gas, Reactor design, Methane, Bioelectrochemical 14 systems, Biocathode, Methanogenic Archaea 


\section{Gas Chromatography}

17

All gas samples were analyzed as doublets (each $250 \mu \mathrm{L}$ ) for their concentrations of methane, hydrogen, carbon dioxide, oxygen and nitrogen in a gas chromatograph of the type Agilent Technologies 6890N. This gas chromatograph, which was equipped with an HP-Plot column ( $30 \mathrm{~m} \times 0.53 \mathrm{~mm} \times 40 \mu \mathrm{m})$, an $\mathrm{HP}_{-} \mathrm{Al}_{2} \mathrm{O}_{3}$ column $(30 \mathrm{~m} \times 0.53 \mathrm{~mm} \times 15 \mu \mathrm{m})$, and an HP-Molsieve column ( $30 \mathrm{~m} \times 0.53 \mathrm{~mm} \times 25 \mu \mathrm{m})$, analyzed the gas components via a flame ionization detector (FID) and a thermal conductivity detector (TCD). Helium was used as carrier gas (flow rate $\mathrm{HP}_{-} \mathrm{Al}_{2} \mathrm{O}_{3}: 5 \mathrm{~mL} / \mathrm{min}$; HP-Molsieve: $10 \mathrm{~mL} / \mathrm{min}$ ). Processing started with keeping the gas samples at a temperature of $50{ }^{\circ} \mathrm{C}$ for $5 \mathrm{~min}$, before raising the temperature by $10{ }^{\circ} \mathrm{C} / \mathrm{min}$ until the final temperature of $120^{\circ} \mathrm{C}$ was reached and held for 3 $\min$. 



33 FigureS2. Scanning electron microscopy pictures of the biofilms. A: Low biofilm growth on inner part of graphite felt. B: Dense biofilm on top of the graphite felt in contact with the membrane. C: Dense biofilm on graphite felt fibers near the current collector. D: Close-up of biofilm on graphite felt near the membrane. 